\title{
In-Vitro and In-Silico Evaluations of Heterocyclic-Containing Diarylpentanoids as Bcl-2 Inhibitors Against LoVo Colorectal Cancer Cells
}

\author{
Sze Wei Leong ${ }^{1, *}$, Suet Lin Chia ${ }^{1,2, * \mathbb{C}}$, Faridah Abas ${ }^{3,4} \mathbb{C}^{-}$and Khatijah Yusoff ${ }^{1,2,5}$ \\ 1 Department of Microbiology, Faculty of Biotechnology and Biomolecular Sciences, Universiti Putra Malaysia, \\ UPM Serdang 43400, Selangor Darul Ehsan, Malaysia; Kyusoff@upm.edu.my \\ 2 UPM-MAKNA Cancer Research Laboratory, Institute of Bioscience, Universiti Putra Malaysia, \\ UPM Serdang 43400, Selangor Darul Ehsan, Malaysia \\ 3 Department of Food Science, Faculty of Food Science and Technology, Universiti Putra Malaysia, \\ UPM Serdang 43400, Selangor, Malaysia; Faridah_abas@upm.edu.my \\ 4 Laboratory of Natural Products, Institute of Bioscience, Universiti Putra Malaysia, \\ UPM Serdang 43400, Selangor Darul Ehsan, Malaysia \\ 5 Malaysia Genome Institute (MGI), National Institute of Biotechnology Malaysia (NIBM), Jalan Bangi, \\ Kajang 43000, Malaysia \\ * Correspondence: leongszewei@upm.edu.my (S.W.L.); suetlin@upm.edu.my (S.L.C.); \\ Tel.: +603-9769-7765 (S.W.L.); +603-9769-8295 (S.L.C.)
}

Academic Editors: Mai Antonello and Loredana Salerno

Received: 26 June 2020; Accepted: 2 August 2020; Published: 26 August 2020

\begin{abstract}
In the present study, we investigated the in-vitro anti-cancer potential of six diarylpentanoids against a panel of BRAF- and KRAS-mutated colorectal cancer cell lines including T84, SW620, LoVo, HT29, NCI-H508, RKO, and LS411N cells. Structure-activity relationship study suggested that the insertions of tetrahydro-4H-thiopyran-4-one and brominated phenyl moieties are essential for better cytotoxicity. Among the evaluated analogs, $2 \mathbf{e}$ has been identified as the lead compound due to its low $\mathrm{IC}_{50}$ values of approximately $1 \mu \mathrm{M}$ across all cancer cell lines and high chemotherapeutic index of 7.1. Anti-proliferative studies on LoVo cells showed that 2e could inhibit cell proliferation and colony formations by inducing G2/M cell cycle arrest. Subsequent cell apoptosis assay confirmed that $\mathbf{2 e}$ is a Bcl-2 inhibitor that could induce intrinsic cell apoptosis by creating a cellular redox imbalance through its direct inhibition on the Bcl-2 protein. Further molecular docking studies revealed that the bromophenyl moieties of $2 \mathbf{e}$ could interact with the Bcl-2 surface pocket through hydrophobic interaction, while the tetrahydro- $4 \mathrm{H}$-thiopyran-4-one fragment could form additional Pi-sulfur and Pi-alkyl interactions in the same binding site. In all, the present results suggest that $2 \mathbf{e}$ could be a potent lead that deserves further modification and investigation in the development of a new Bcl-2 inhibitor.
\end{abstract}

Keywords: diarylpentanoids; colorectal cancer; cytotoxicity; anti-proliferative; cell cycle; apoptosis; Bcl-2 inhibitor; molecular docking

\section{Introduction}

Colorectal cancer (CRC) is the 3rd most common type of cancer and 2nd leading cause of cancer death worldwide. According to statistics by Globocan, there were approximately 1.8 million new CRC cases in 2018 and the number of CRC-related deaths has surpassed 850,000 in the same year. Worse still, these numbers are estimated to increase to 3.1 and 1.3 million cases, respectively, by 2040 [1]. To date, chemotherapy remains as the mainstream in the management of CRC. Among the currently available chemotherapy agents, oxaliplatin and 5-fluorouracil (5-FU) are the two most common drugs 
that have been widely used in treating CRC. Previous studies showed that the combination of these compounds could simultaneously disrupt the synthesis and the replication of DNA, thereby effectively suppressing the tumor growth [2,3]. Based on this, a mixture of oxaliplatin and 5-FU has been used as a synergistic treatment against all stages of CRC, particularly metastasis [4]. Despite such a cocktail successfully improving the CRC tumor response and prolonging the survival of CRC patients, its associated side effects including nausea, cardiotoxicity and neurotoxicity remain as issues of concern $[5,6]$. These undesirable side effects not only hinder the full therapeutic potential of the respective chemotherapy but also reduce the quality of life of the cancer patients. On this account, alternative effective anti-cancer agents with improved safety profile are urgently needed.

Turmeric is a yellow powder obtained from the dried rhizome of Curcuma longa Linn. that has been widely used as a spice for food flavoring and coloring especially in Asian cuisines. Apart from food preparation, turmeric has also been used in traditional remedies to treat several illness and injuries including eye infections, skin rashes, indigestion, insect bites and burns [7]. Due to its medicinal values, turmeric has received a great deal of attention by researchers in the past few decades. As the major component of turmeric, curcumin (Figure 1) has been studied extensively for its biological activities and therapeutic potential. Many studies revealed that curcumin possesses strong antioxidant and inflammatory activities as it was found to scavenge several types of free radical species as well as inhibit a wide range of pro-inflammatory cytokines including tumor necrosis factor alpha (TNF- $\alpha)$, interleukins, cyclooxygenase-2 (COX-2) and inducible nitric oxide synthase (iNOS) [8-11]. In addition, curcumin was also found to exhibit prominent anti-cancer potential based on its growth-inhibiting and apoptosis-inducing abilities against multiple cancer cell lines [12-15]. Interestingly, this naturally occurring small molecule has displayed excellent safety profiles in both preclinical and clinical studies which prompted it to be a promising candidate in the search for a safer chemotherapeutic agent $[16,17]$. Unfortunately, the practical use of curcumin is limited by its low bioavailability due to the instability of the molecular structure. The $\beta$-diketone moiety of curcumin has been reported to be highly reactive and easily dissociated by several metabolic and detoxification enzymes such as aldehyde dehydrogenases and aldo-keto reductases [18-20]. On this account, structural optimisation to remove the unstable $\beta$-diketone moiety of curcumin has been the focus of curcuminoid-based studies.

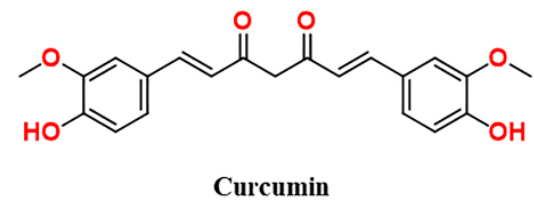

Figure 1. Chemical structure of curcumin.

Cyclic monocarbonyl diarylpentanoids are one of the bioactive families that are derived from curcumin by eliminating the reactive $\beta$-diketone moiety. Apart from showing improved chemical and metabolic stability, these diketone-free curcuminoids were also found to exhibit better medicinal potential than that of curcumin, particularly as anti-cancer agents [21,22]. Many studies reported that cyclic monocarbonyl diarylpentanoids possess potent anti-cancer properties based on their superior inhibitory activity against the growth of various cancer cell lines including breast, lung, colon and prostate cancer cells [13,23-25]. Several downstream mechanistic studies revealed that the remarkable anti-cancer properties of these diarylpentanoids are due to their anti-angiogenic and apoptosis-inducing activities, which resulted from VEGF inhibition and caspases activation, respectively [26-28]. In addition, cyclic monocarbonyl diarylpentanoids were also found to be effective in-vivo based on their positive suppression against tumor growth in several mice xenograft models $[29,30]$. Interestingly, recent studies demonstrated that this diarylpentanoid family possesses a curcumin-like safety profile as they were shown to be non-toxic in acute toxicity evaluations of several anti-inflammatory animal models [31,32]. Based on this, cyclic monocarbonyl diarylpentanoids 
are therefore of interest and worthy for further investigation in the search of safer anti-cancer drugs. Figure 2 depicts the general structures of previously reported cyclic monocarbonyl diarylpentanoids.

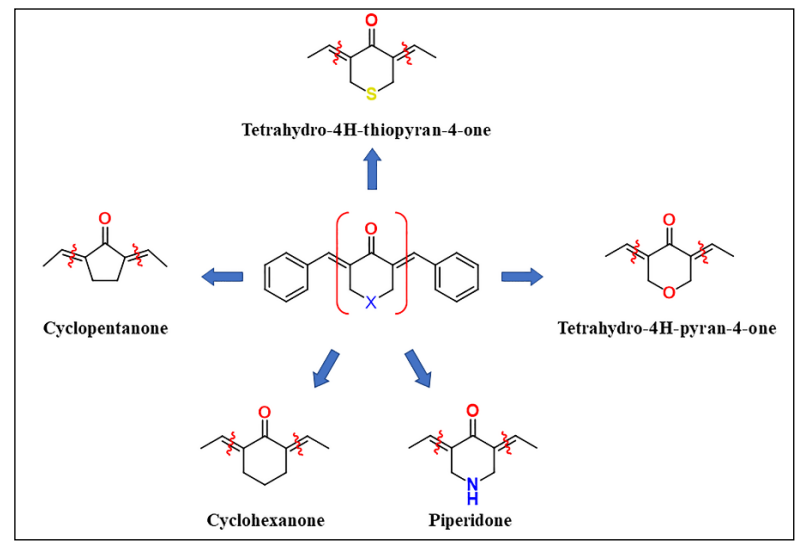

Figure 2. General structures of reported cyclic monocarbonyl diarylpentanoids.

To the best of our knowledge, previous studies were mainly focused on the cycloalkanone, piperidone and tetrahydropyranone derivatives of diarylpentanoid as they were usually shown to possess promising anti-cancer activity. Despite the respective tetrahydrothiopyranone derivatives being rarely explored, their anti-cancer potential should not be underestimated as the cytotoxicity enhancing effects of the tetrahydropyranone moiety has recently been reported [33,34]. On the basis of this, the aim of the present study was to evaluate the anti-cancer potential of tetrahydro- $4 H$-thiopyran-4-one-containing diarylpentanoids and compare to that of their respective cyclohexanone-based analogs.

\section{Results and Discussions}

\subsection{Chemistry}

Scheme 1 outlines the synthetic pathway of cyclohexanone- and tetrahydro- $4 H$-thiopyran4-one-containing diarylpentanoids. As depicted, 2a-2e were achieved through simple aldo-condensation by reacting cyclohexanone or tetrahydro- $4 H$-thiopyran-4-one with appropriate benzaldehydes in the presence of $10 \mathrm{M}$ sodium hydroxide. The formations of $\mathbf{2 a}-\mathbf{2 e}$ were confirmed by the detection of a singlet at the chemical shift of 7.5-8.0 ppm in their respective proton NMR, where such signals represent the presence of benzylidene vinylic groups. All synthesised compounds were purified by column chromatography and characterized by ${ }^{1} \mathrm{H}-\mathrm{NMR},{ }^{13} \mathrm{C}-\mathrm{NMR}$, and high-resolution electron impact-mass spectrometry (HRMS). The melting point of known compounds ( $\mathbf{2} \mathbf{a}, \mathbf{2} \mathbf{b}$ and $\mathbf{2} \mathbf{f})$ were compared to that of previously reported data [35-38]. Prior to assays, the purity of synthesized compounds was confirmed to be greater than $95 \%$ based on their respective HPLC profiles (Supplementary Materials). The synthesized compounds are listed in Table 1 and their respective chemical structures can be found in both Table 1 and Figures 9-14.

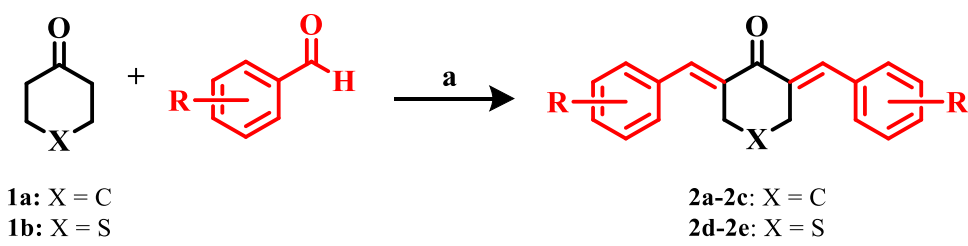

Scheme 1. General synthetic steps for $\mathbf{2 a}-\mathbf{2} \mathbf{e}^{\mathrm{x}}$. xReagents and conditions: (a) benzaldehyde, EtOH, $10 \mathrm{M} \mathrm{NaOH}$, RT (overnight). 
Table 1. Chemical Structures of 2a-2e.

Cmpd

\subsection{Biological Studies}

\subsubsection{In-Vitro Cytotoxicity Analysis}

The in-vitro cytotoxic activity of the synthesized compounds on seven human CRC cell lines including KRAS (T84, SW620, LoVo) and BRAF (HT29, NCI-H508, RKO and LS411N) mutated cells were determined by MTT assay as previously described [39]. The $\mathrm{IC}_{50}$ values obtained are summarized in Table 2 in which 5-FU and normal human dermal fibroblasts (NHDF) were used as controls. Meanwhile, a heatmap (Figure 3) was also generated using GraphPad Prism v7.0 (GraphPad Software, La Jolla, CA, USA) to visualize the cytotoxic trends of synthesized compounds graphically.

Table 2. Cytotoxicity of 2a-2e on T84, SW620, LoVo, HT29, NCI-H508, RKO, LS411N and normal human dermal fibroblast (NHDF) cell lines at $72 \mathrm{~h}$ post-treatment.

\begin{tabular}{|c|c|c|c|c|c|c|c|c|c|c|c|}
\hline \multirow{2}{*}{ Compound } & \multirow[t]{2}{*}{$X$} & \multirow[t]{2}{*}{$\mathbf{R}$} & \multicolumn{3}{|c|}{ KRAS } & \multicolumn{4}{|c|}{$\mathrm{IC}_{50}(\mu \mathrm{M})$} & \multirow[t]{2}{*}{ NHDF } & \multirow{2}{*}{$\begin{array}{l}\text { Chemo- } \\
\text { Therapeutic } \\
\text { Index }\end{array}$} \\
\hline & & & T84 & SW620 & LoVo & HT29 & NCI-H508 & RKO & LS411N & & \\
\hline 5-FU & - & - & $>10$ & $>10$ & 3.3 & $>10$ & 8.6 & 2.9 & 4.6 & $>20$ & - \\
\hline $2 a$ & $\mathrm{C}$ & 2-OMe & $>10$ & $>10$ & $>10$ & $>10$ & $>10$ & $>10$ & $>10$ & $>20$ & - \\
\hline $2 b$ & $\mathrm{C}$ & $2-\mathrm{Br}$ & $>10$ & 8.9 & $>10$ & $>10$ & 7.8 & $>10$ & $>10$ & $>20$ & - \\
\hline $2 c$ & $\mathrm{C}$ & $3,4-F$ & 3.3 & 3.2 & 3.3 & 5.4 & 3.3 & 2.6 & 3.7 & 12.9 & $2.3-5.0$ \\
\hline $2 d$ & $S$ & 2-OMe & $>10$ & $>10$ & 6.9 & $>10$ & 5.3 & 7.1 & 5.8 & 9.7 & $1.4-1.8$ \\
\hline $2 \mathrm{e}$ & $\mathrm{S}$ & $2-\mathrm{Br}$ & 1.6 & 1.4 & 1.0 & 2.1 & 1.1 & 1.2 & 1.3 & 7.1 & $3.4-7.1$ \\
\hline $2 f$ & $S$ & 3,4-F & $>10$ & 2.9 & 5.1 & $>10$ & 6.2 & 2.4 & 5.9 & 2.0 & $0.3-0.8$ \\
\hline
\end{tabular}

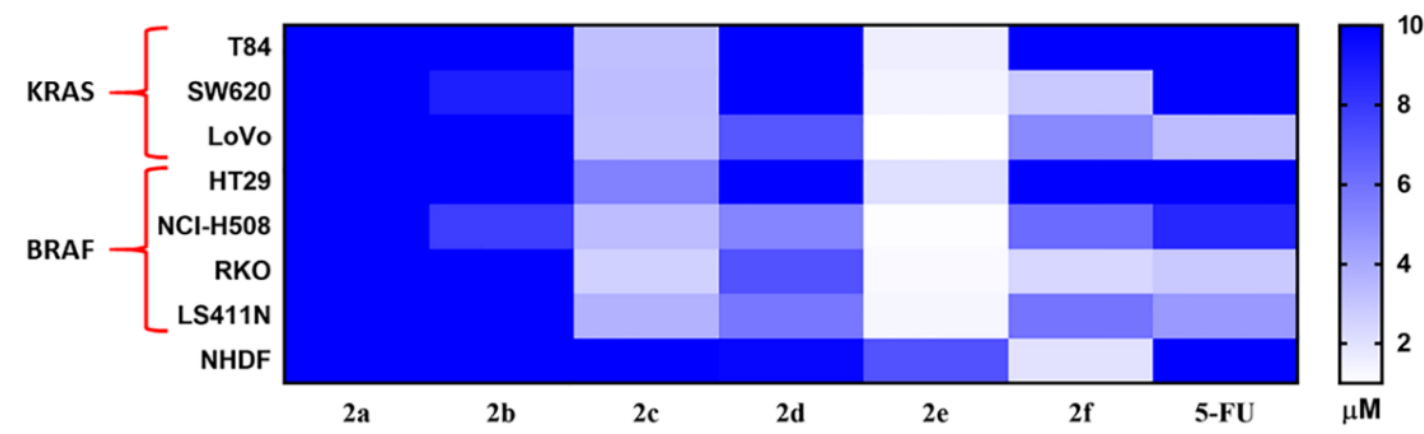

Figure 3. Overall $\mathrm{IC}_{50}$ distribution of 2a-2e against T84, SW620, LoVo, HT29, NCI-H508, RKO, LS411N and NHDF cell lines.

As shown in Table 2 and Figure 3, 2c and 2e displayed excellent cytotoxicity effects against all tested CRC cell lines $(<5 \mu \mathrm{M})$ in which $2 \mathbf{e}$ was found to be the most promising candidate based 
on its high chemotherapeutic index of 7.1 and low $\mathrm{IC}_{50}$ values ranging from 1.0 to $2.1 \mu \mathrm{M}$. On top of this, 2e displayed at least 2.5-fold better cytotoxicity than that of the positive control, 5-FU, which further highlighted its potential to be developed as a chemotherapeutic agent. On the other hand, $\mathbf{2 f}$ was found to be another strong cytotoxic agent as it successfully inhibited several CRC cell lines with $\mathrm{IC}_{50}$ values ranging from 2.4 to $6.2 \mu \mathrm{M}$. However, although $2 \mathrm{f}$ exhibits a certain degree of anti-cancer activity, its therapeutic potential is completely offset by its undesirable cytotoxic effects on normal human cells (NHDF). Of note, all synthesized compounds displayed similar cytotoxic effects against both KRAS- and BRAF-mutated CRC cell lines, which implies that both cyclohexanoneand tetrahydro-4H-thiopyran-4-one-containing diarylpentanoids may not be BRAF- or KRAS-specific inhibitors. A subsequent SAR study revealed that the tetrahydro- $4 H$-thiopyran-4-one fragment is crucial for improving cytotoxicity of diarylpentanoids, as both $\mathbf{2 d}$ and $\mathbf{2 e}$ displayed much better cytotoxicity than their respective cyclohexanone analogs (2a and $\mathbf{2 b}$ ). Interestingly, substitution of halogen at the ortho position of phenyl rings appeared to be essential for cytotoxicity enhancement as $\mathbf{2} \mathbf{b}$ and $\mathbf{2 e}$, the two ortho-brominated diarylpentanoids, displayed stronger activity than their ortho-methoxylated analogs (2a and $\mathbf{2 d}$ ). In contrast, the 3,4-difluorophenyl group was found to be undesirable as compounds with such a moiety displayed significantly higher cytotoxicity against normal human cells. These observations are consistent with our previous studies in which we reported that insertion of the ortho-halogenated phenyl moiety could improve the cytotoxicity of diarypentanoids while the presence of the 3,4-difluorophenyl moiety may increase compounds' cytotoxicity against normal human cells $[39,40]$. Thus, in view of its potent cytotoxicity and high chemotherapeutic index, 2e was selected for further mechanistic investigation.

\subsubsection{In-Vitro Anti-Proliferative Analysis}

To identify the potential cytotoxic mechanisms of $\mathbf{2 e}$, morphological inspection, colony formation and cell cycle analyses were performed. The results obtained are summarized and compiled into Figure 4.
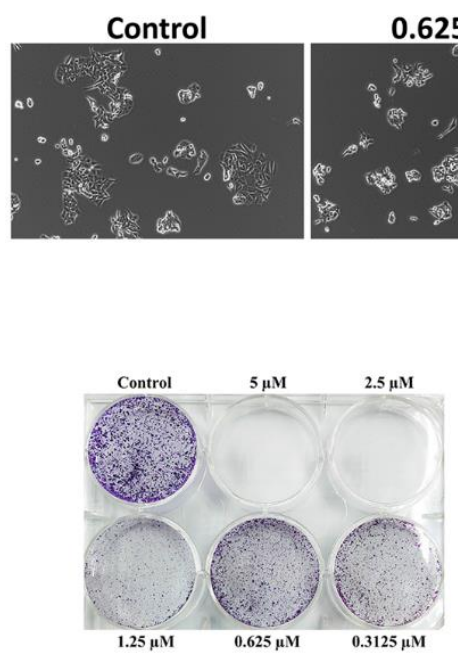

(B)

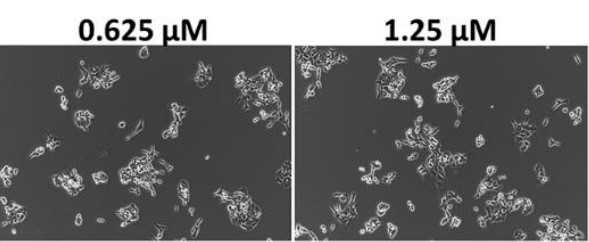

(A)

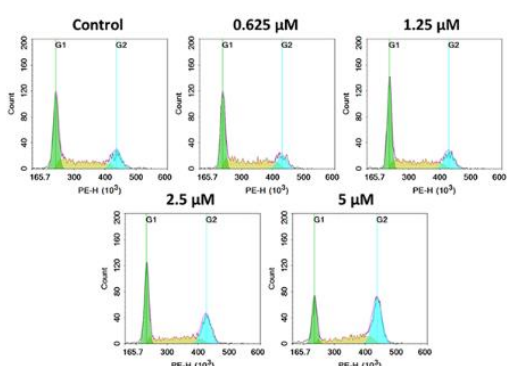

(C)
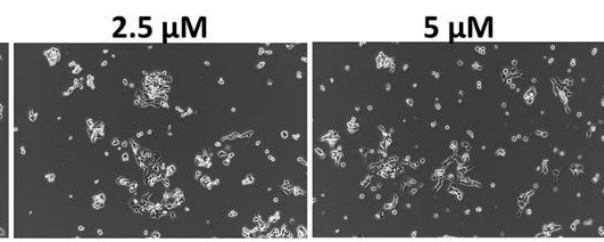

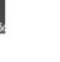


and apoptosis-inducing activities. In addition to this, $2 \mathbf{e}$ was also found to inhibit the colony formation of LoVo cells in a dose-dependent manner (Figure 4B), which thereby confirmed its anti-proliferative activity. To further investigate the possible anti-proliferative mechanism, 2e was subjected to flow cytometry-based cell cycle analysis and the results obtained are summarized in Figure 4C,D. Based on the results obtained, 2e was found to induce G2/M-phase cell arrest in LoVo cells, as treatments with 2.5 and $5 \mu \mathrm{M}$ of $2 \mathbf{e}$ successfully increased the intensity of the G2/M peak. Thus, taking morphological inspection, colony formation and cell cycle analysis together, the present results strongly suggest that $\mathbf{2 e}$ is a potent anti-proliferative agent that could induce G2/M-phase cell arrest.

\subsubsection{In-Vitro Cell Apoptosis Analysis}

To further investigate the underlying cytotoxic mechanisms of $\mathbf{2 e}$ against LoVo cells, both flow cytometry and Western blot analyses were performed. The results obtained are summarised and compiled into Figure 5.

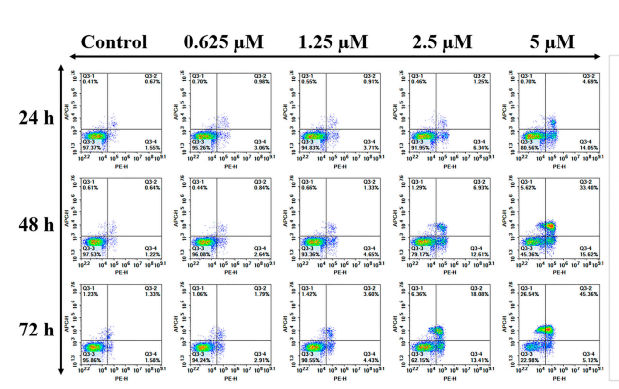

(A)
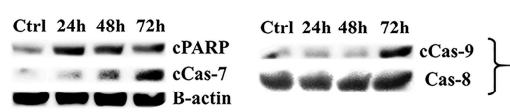

(C)

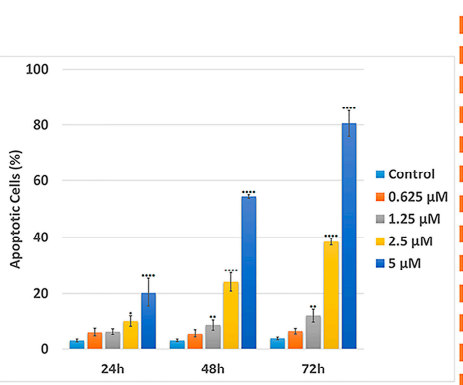

(B)

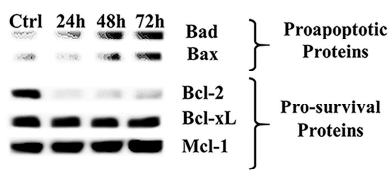

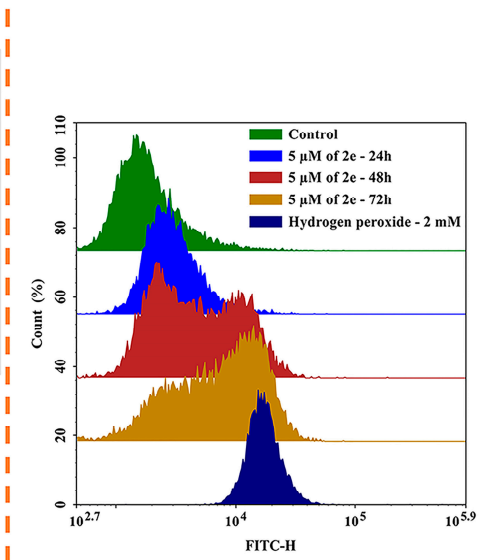

(D)

Figure 5. (A) Apoptosis profiles of LoVo cells at $24 \mathrm{~h}, 48 \mathrm{~h}$ and $72 \mathrm{~h}$ of post-treatments with $0.625,1.25$, 2.5 and $5 \mu \mathrm{M}$ of $2 \mathbf{e}$. (B) Comparison of total apoptotic cells induced by $2 \mathbf{e}$ at $24 \mathrm{~h}, 48 \mathrm{~h}$ and $72 \mathrm{~h}$ of post-treatments with $0.625,1.25,2.5$ and $5 \mu \mathrm{M}$ of 2e. (C) Western blot analysis on cPARP, caspases and Bcl-2 family proteins expression in 2e-treated $(5 \mu \mathrm{M})$ LoVo cells at $24 \mathrm{~h}, 48 \mathrm{~h}$, and $72 \mathrm{~h}$ of post-treatments. (D) Representative flow cytometry-based ROS profiles of 2e-treated $(5 \mu \mathrm{M})$ LoVo cells at $24 \mathrm{~h}, 48 \mathrm{~h}$ and $72 \mathrm{~h}$ of post-treatments. ${ }^{*}$ is representing the level of significant difference. The more it has, the higher the significant difference it is compared to the control.

As shown in the annexin V-based flow cytometry analysis (Figure 5A), treatment with 2.5 and $5 \mu \mathrm{M}$ of $2 \mathbf{e}$ shifted the density plots from left to right and upper right. This indicates that $2 \mathbf{e}$ could induce cellular apoptosis in LoVo cells as such a shifting pattern reflects the onset and progression of cellular apoptosis. Similar to that of the cell cycle study, 0.625 and $1.25 \mu \mathrm{M}$ of $2 \mathbf{e}$ exhibited minimal insignificant effects on LoVo cells (Figure 5B), which implied that $2.5 \mu \mathrm{M}$ could be the lowest in vitro effective dose of $\mathbf{2 e}$ against LoVo cells. In order to validate the apoptosis inducing ability of $\mathbf{2 e}$, Western blot studies against cleaved PARP and cleaved caspase-7 were carried out.

As depicted in Figure 5C, both cleaved PARP and caspase-7, a hallmark of apoptotic cell death, were increased after $24 \mathrm{~h}$ of treatments, thus confirming the apoptotic nature of $2 \mathbf{e}$ [41]. This is in consistent with that of the annexin V-based assay in which the apoptotic cells were detected as early as $24 \mathrm{~h}$ post-treatment. To further uncover the underlying apoptotic mechanism of $\mathbf{2 e}$, its effects on initiator caspases and proapoptotic proteins were studied. According to the results, $2 \mathbf{e}$ was suggested to be an intrinsic apoptosis inducer based on its ability to activate the cleavage of caspase- 9 while leaving caspase-8 unaffected (with no detection of cleaved caspase-8). This finding is further supported by the up-regulation of Bad and Bax proteins, as they are the common proteins that are actively involved in the 
progression of intrinsic apoptosis. However, unlike cleaved caspase-7 and cleaved PARP, the changes in Bad and Bax expression is only detectable after $48 \mathrm{~h}$ of post-treatment. This suggests that Bax and Bad activation might not be the primary apoptotic pathway induced by $\mathbf{2 e}$. Thus, in continuing our efforts to reveal the underlying mechanism, effects of $2 \mathbf{e}$ on anti-apoptotic proteins including Bcl-2, Bcl-xL and Mcl-2 were examined. As presented in Figure 5C, Bcl-2 was significantly inhibited by $2 \mathbf{e}$ as early as $24 \mathrm{~h}$ post-treatment, while the expressions of both Bcl-xL and Mcl-1 remained unaffected, even if the treatments were extended to $72 \mathrm{~h}$. This finding suggests that Bcl-2 could be the primary target of $\mathbf{2 e}$ as its down-regulation occurred earlier than the up-regulation of Bax and Bad.

In general, Bcl-2 is an anti-apoptotic protein that is well-known for its ability to prevent the permeabilisation of the mitochondrial outer membrane induced by Bak and Bax, thus protecting cells from apoptosis [42]. However, recent evidence indicates that Bcl-2 is not only an anti-apoptotic protein but also a cellular ROS regulator whereby knock-down of Bcl-2 increased subjects' oxidative susceptibility and responses in both in-vitro and in-vivo models [43-45]. Based upon this, it is reasonable to suggest that $\mathrm{Bcl}-2$ inhibition may lead to redox imbalance and thus increases the cellular ROS level. Therefore, with the aim to validate the role of Bcl-2 as a primary target of $\mathbf{2 e}$, we further examined the effects of $\mathbf{2 e}$ on cellular ROS through DCFH-DA-based analysis.

As shown in Figure 5D, $24 \mathrm{~h}$ of treatment with 2e shifted the histogram to the right as a whole, implying a rapid increment in cellular ROS level. Since Bax and Bad were not activated at this time point, such an increment is therefore evidence of redox imbalance, which resulted from Bcl-2 inhibition. Based upon this, the role Bcl-2 as primary target of $2 \mathbf{e}$ is thus confirmed. Of note, when the treatment was prolonged to $48 \mathrm{~h}$ and $72 \mathrm{~h}$, an additional peak appeared at the rightmost point of the histogram, which implies a secondary increment of cellular ROS. This secondary increment could be rationalised by the stimulation of ROS, which resulted from the vicious cycle of oxidative stress induced by Bcl-2 inhibition. Taken together, the present results confirmed that $2 \mathbf{e}$ is a Bcl-2 inhibitor that can induce intrinsic apoptosis by disrupting the cellular redox state. The overall apoptosis mechanism induced by $\mathbf{2 e}$ is summarised in Figure 6.

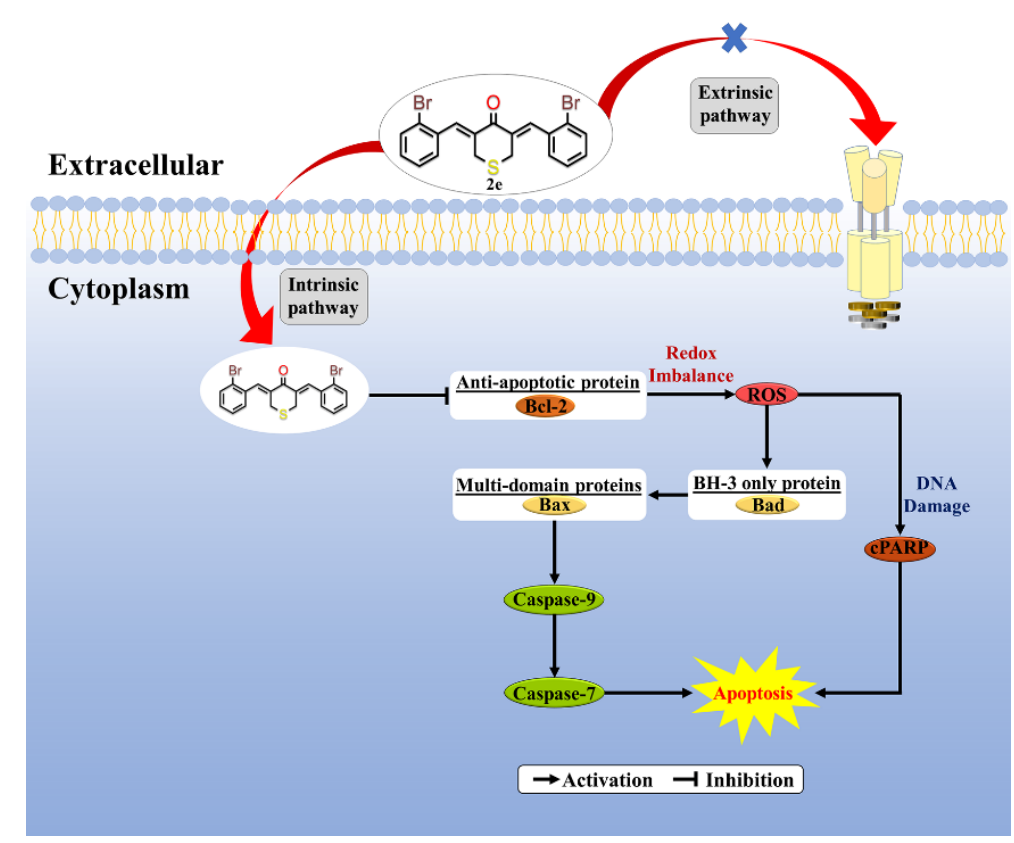

Figure 6. Illustration of the intrinsic apoptosis mechanism induced by $2 \mathbf{e}$ in LoVo cells.

\subsubsection{In-Silico Molecular Modelling Analysis}

In order to gain further insights into the binding mode of $2 \mathbf{e}$ in Bcl-2, flexible docking was performed using Discovery Studio 3.1. Prior to docking 2e into Bcl-2, the docking parameters 
were first validated by the re-docking of the co-crystallised ligand into the active site of the protein. The parameters are considered acceptable if the root mean square deviation (RMSD) value obtained from the re-docked and native ligands does not exceed $2.0 \AA$ [46].

As depicted in Figure 7, both redocked (yellow) and native (blue) ABT-263 were found to interact with Bcl-2 in very similar conformations, of which the respective RMSD value obtained was $1.8 \AA$. This implies that the selected parameters are acceptable and could be used further for the docking studies of $\mathbf{2 e}$. In order to compare and contrast the binding interactions contributed by tetrahydro-4H-thiopyran-4-one and cyclohexanone fragments, $\mathbf{2} \mathbf{b}$ was also included in the present docking analysis. Figure 8 illustrates the binding interactions of $\mathbf{2 b}$ and $\mathbf{2 e}$ in Bcl-2.

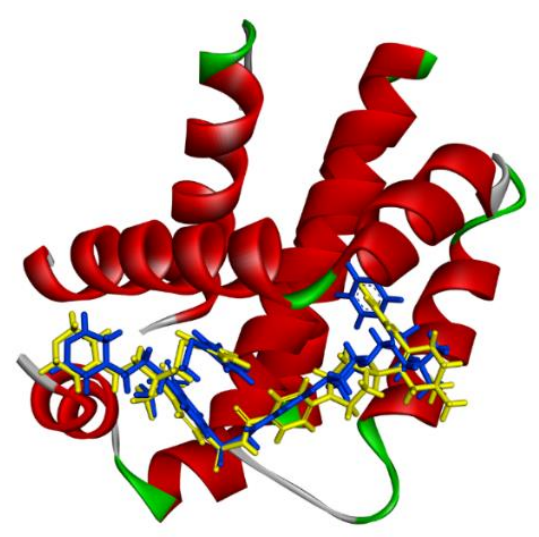

Figure 7. Overlay of re-docked (yellow) and native (blue) conformations of ABT-263 in Bcl-2 (PDB ID: 4LVT).

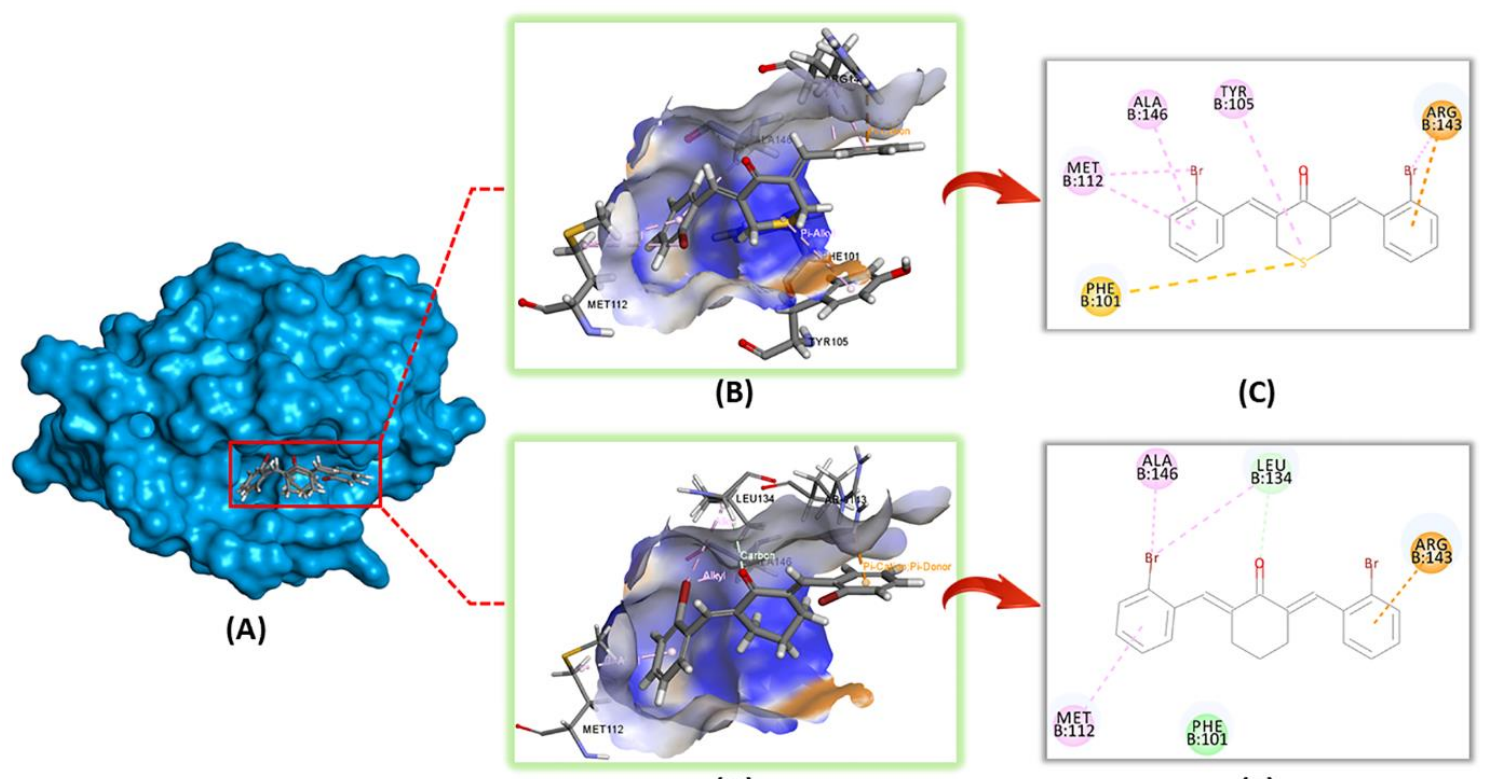

(D)

(E)

Figure 8. Molecular docking model of 2e with the Bcl-2 protein (PDB: 4LVT). (A) 3D conformation positions of $\mathbf{2 b}$ and $\mathbf{2 e}$ in the surface pocket of Bcl-2. (B) Key interactions of $\mathbf{2 e}$ in the surface pocket of Bcl-2. (C) 2D graph of $\mathbf{2 e}$ in the surface pocket of Bcl-2. (D) Key interactions of $\mathbf{2 b}$ at the surface pocket of Bcl-2. (E) 2D graph of $\mathbf{2 b}$ in the surface pocket of Bcl-2.

As shown in Figure 8A, both $\mathbf{2 b}$ and $\mathbf{2 e}$ bound to the surface pocket of bcl-2 protein in very similar conformations. This implies that $\mathbf{2} \mathbf{b}$ and $\mathbf{2 e}$ might share some similarity in interacting with the $\mathrm{Bcl}-2$ protein. A closer look at their respective binding interactions (Figure 8B-D) shows that 
the bromophenyl fragments of both compounds could interact with the Bcl-2 surface pocket by forming hydrophobic interactions with several amino acid residues including ALA-146, MET-112 and ARG-143. This rationalises the increased cytotoxicity seen by brominated analogs, as the bromo group is more hydrophobic than methoxyl moiety. More importantly, the present docking analysis revealed that the thio-moiety of $2 \mathbf{e}$ could form additional Pi-sulfur and Pi-alkyl interactions with PHE-101 and TYR-105 residues, respectively, thus explaining the improved cytotoxicity of tetetrahydro- $4 H$-thiopyran-4-one-containing analogs. The in silico molecular docking results are summarized in Table 3.

Table 3. Data resulted from the molecular docking of $\mathbf{2 b}$ and $\mathbf{2 e}$ in Bcl-2.

\begin{tabular}{|c|c|c|c|c|}
\hline Compound & Structure & $\begin{array}{c}\text { Interacting } \\
\text { Amino Acid Residue }\end{array}$ & Type of Interaction & Bonding Distance (Å) \\
\hline \multirow{5}{*}{$2 b$} & & ALA-146 & Alkyl & 3.84 \\
\hline & 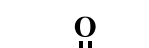 & MET-112 & Pi-Alkyl & 4.12 \\
\hline & & ARG-143 & Pi-Cation & 2.39 \\
\hline & & LEU-134 & Alkyl & 4.8 \\
\hline & & & Carbon & 2.49 \\
\hline \multirow{8}{*}{$2 \mathrm{e}$} & & ALA-146 & Pi-Alkyl & 5.20 \\
\hline & & MET-112 & Pi-Alkyl & 4.76 \\
\hline & & \multirow{4}{*}{ ARG-143 } & Alkyl & 4.75 \\
\hline & & & Alkyl & 3.93 \\
\hline & & & Pi-Cation & 3.67 \\
\hline & & & Pi-Alkyl & 5.14 \\
\hline & & TYR-105 & Pi-Alkyl & 5.24 \\
\hline & & PHE-101 & Pi-Sulfur & 4.78 \\
\hline
\end{tabular}

\section{Materials and Methods}

\subsection{Chemistry}

Chemicals, reagents and solvents were purchased from Sigma-Aldrich and Merck, and were used without purification. The chemical reactions were routinely checked on $0.20 \mathrm{~mm}$ Merck TLC plate silica gel 60 F254 using a solvent system of ethyl acetate/hexane (15:85). Compound purifications were performed using column chromatography on Merck silica gel 60 (mesh 70-230). Melting points were determined using the Fisher-Johns melting point apparatus and were uncorrected. High-resolution electron ionisation-mass spectrometry (HREI-MS) was determined using a DFS high resolution GC/MS (Thermo Scientific, San Jose, CA, USA). Nuclear magnetic resonance spectra were recorded on a Varian $500 \mathrm{MHz}$ NMR Spectrometer.

General Procedure for the Synthesis of 2a-2e

Cyclohexanone or tetrahydro- $4 H$-thiopyran-4-one $(1 \mathrm{mmol})$ and appropriate aromatic aldehydes ( $2 \mathrm{mmol}$ ) were reacted overnight in $20 \mathrm{~mL}$ of absolute ethanol in the presence of a catalytic amount of $10 \mathrm{M} \mathrm{NaOH}$ aqueous solution. Then, the reaction mixture was poured into a $250 \mathrm{~mL}$ beaker containing $100 \mathrm{~mL}$ of $3 \mathrm{M} \mathrm{HCl}$ followed by extraction with ethyl acetate. The ethyl acetate layer was collected and dried over anhydrous magnesium sulfate followed by evaporation with a rotatory evaporator to give the crude of the desired compounds. Purifications with chromatography using an ethyl acetate/hexane (10:90) solvent system were then performed to obtain pure diarylpentanoids (Figures 9-14).

2,6-Bis(2-methoxybenzylidene)cyclohexanone (2a). (Figure 9). Yellow gummy solid; yield: 87\%; m.p. found: m.p. reported: Mass calculated: 334.1569; Mass found: $334.1588 .{ }^{1} \mathrm{H}$ NMR (500 MHz, chloroform- $d$ ) $\delta$ ppm $1.74\left(d_{\mathrm{t}}, J=12.21,6.24 \mathrm{~Hz}, 2 \mathrm{H}\right) 2.84(\mathrm{t}, J=5.49 \mathrm{~Hz}, 4 \mathrm{H}) 3.85(\mathrm{~s}, 6 \mathrm{H}) 6.91(\mathrm{~d}, J=8.23 \mathrm{~Hz}, 2 \mathrm{H}) 6.96$ $(\mathrm{t}, J=7.41 \mathrm{~Hz}, 2 \mathrm{H}) 7.28-7.35(\mathrm{~m}, 4 \mathrm{H}) 7.98(\mathrm{~s}, 2 \mathrm{H}) .{ }^{13} \mathrm{C}$ NMR $(126 \mathrm{MHz}$, chloroform-d $) \delta \mathrm{ppm} 23.5,28.8$, $55.5,110.6,119.9,125.1,123.0,130.3,132.5,136.5,158.3,190.6$. 


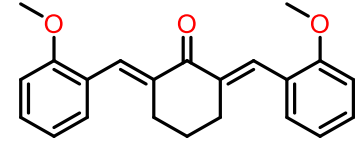

Molecular Weight: 334.4150

Figure 9. Chemical structure of $\mathbf{2 a}$.<smiles>O=C1/C(=C/c2ccccc2Br)CCC/C1=C\c1ccccc1Br</smiles>

2b

Molecular Weight: 432.1550

Figure 10. Chemical structure of $\mathbf{2 b}$.

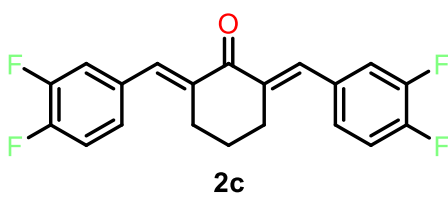

Molecular Weight: 346.3246

Figure 11. Chemical structure of 2c.

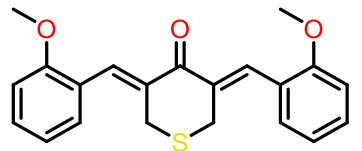

2d

Molecular Weight: 352.4480

Figure 12. Chemical structure of $\mathbf{2 d}$.

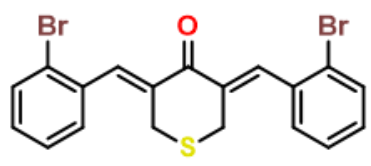

$2 \mathrm{e}$

Molecular Weight: 450.1880

Figure 13. Chemical structure of $\mathbf{2 e}$

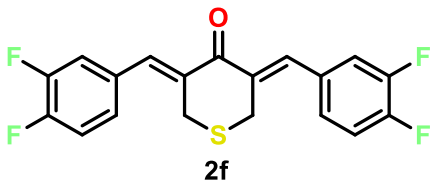

Molecular Weight: 364.3576

Figure 14. Chemical structure of $\mathbf{2 f}$.

2,6-Bis(2-bromobenzylidene)cyclohexanone (2b) (Figure 10). Yellow solid; yield: 97 \%; m.p. found: 106-107 ${ }^{\circ} \mathrm{C}$; m.p. reported: $120{ }^{\circ} \mathrm{C}$; Mass calculated: 429.9568; Mass found: 429.9585. ${ }^{1} \mathrm{H} \mathrm{NMR}(500 \mathrm{MHz}$, chloroform- $d$ ) $\delta$ ppm 1.76 (quin, $J=6.04 \mathrm{~Hz}, 2 \mathrm{H}) 2.75(\mathrm{t}, J=5.21 \mathrm{~Hz}, 4 \mathrm{H}) 7.17-7.22(\mathrm{~m}, 2 \mathrm{H}) 7.29-7.35$ $(\mathrm{m}, 4 \mathrm{H}) 7.64(\mathrm{~d}, J=8.23 \mathrm{~Hz}, 2 \mathrm{H}) 7.85$ (s, $2 \mathrm{H}) .{ }^{13} \mathrm{C}$ NMR $(126 \mathrm{MHz}$, chloroform- $d$ ) $\delta$ ppm 23.1, 28.3, $110.0,125.1,126.9,129.7,130.5,132.9,136.2,136.4,137.4,189.6$ 
2,6-Bis(3,4-difluorobenzylidene)cyclohexanone (2c) (Figure 11). Brown solid; yield: 43\%; m.p.: 90-91 ${ }^{\circ} \mathrm{C}$; Mass calculated: 346.0981; Mass found: 346.1094. ${ }^{1} \mathrm{H}$ NMR $(500 \mathrm{MHz}$, chloroform- $d$ ) $\delta$ ppm 1.82 (quin, $J=6.18 \mathrm{~Hz}, 2 \mathrm{H}) 2.89(\mathrm{t}, J=5.21 \mathrm{~Hz}, 4 \mathrm{H}) 7.15-7.23(\mathrm{~m}, 4 \mathrm{H}) 7.25-7.32(\mathrm{~m}, 2 \mathrm{H}) 7.67(\mathrm{~s}, 2 \mathrm{H}) .{ }^{13} \mathrm{C}$ NMR (126 MHz, chloroform- $d$ ) d ppm 22.62, 28.19, 117.32, 117.46, 118.75, 118.88, 126.98, 127.00, 127.02, 127.05, $132.76,132.79,132.80,132.83,134.97,136.45,136.47,149.04,149.15,149.24,149.34,151.02,151.12,151.25$, $151.35,189.6$

3,5-Bis(2-methoxybenzylidene)tetrahydro-4H-thiopyran-4-one (2d) (Figure 12). Pale yellow solid; yield: $83 \%$; m.p.: $120-121{ }^{\circ} \mathrm{C}$; Mass calculated: 352.1133; Mass found: $352.1145 .{ }^{1} \mathrm{H}$ NMR $(500 \mathrm{MHz}$, chloroform- $d$ ) $\delta$ ppm $3.81(\mathrm{~s}, 4 \mathrm{H}) 3.86(\mathrm{~s}, 6 \mathrm{H}) 6.93(\mathrm{~d}, J=8.23 \mathrm{~Hz}, 2 \mathrm{H}) 6.97(\mathrm{t}, J=7.41 \mathrm{~Hz}, 2 \mathrm{H}) 7.20-7.28$ $(\mathrm{m}, 2 \mathrm{H}) 7.34(\mathrm{t}, J=7.96 \mathrm{~Hz}, 2 \mathrm{H}) 7.91(\mathrm{~s}, 2 \mathrm{H}) .{ }^{13} \mathrm{C}$ NMR $(126 \mathrm{MHz}$, chloroform-d) d ppm 30.3, 55.5, $110.8,120.1,124.3,130.4,130.4,132.9,134.3,158.2,189.3$

3,5-Bis(2-bromobenzylidene)tetrahydro-4H-thiopyran-4-one (2e) (Figure 13). Pale yellow solid; yield: 78 \%; m.p.: $158-160{ }^{\circ} \mathrm{C}$; Mass calculated: 447.9132; Mass found: 447.9140. ${ }^{1} \mathrm{H}$ NMR $(500 \mathrm{MHz}$, chloroform- $d$ ) $\delta$ ppm $3.73(\mathrm{~s}, 4 \mathrm{H}) 7.20-7.25(\mathrm{~m}, 2 \mathrm{H}) 7.27(\mathrm{~d}, J=5.49 \mathrm{~Hz}, 2 \mathrm{H}) 7.32-7.37(\mathrm{~m}, 2 \mathrm{H}) 7.65(\mathrm{~d}, J=8.23 \mathrm{~Hz}, 2$ H) 7.80 (s, $2 \mathrm{H}) .{ }^{13} \mathrm{C}$ NMR $(126 \mathrm{MHz}$, chloroform- $d$ ) $\delta \mathrm{ppm} 29.7,124.8,127.2,130.1$, 130.4, 133.2, 135.1, $135.5,136.3,188.5$

3,5-Bis(3,4-difluorobenzylidene)tetrahydro-4H-thiopyran-4-one (2f) (Figure 14). Pale yellow solid; yield: $55 \%$; m.p. found: $124-125^{\circ} \mathrm{C}$; m.p. reported: $135-137^{\circ} \mathrm{C}$; Mass calculated: 364.0545 ; Mass found: 364.0558. ${ }^{1} \mathrm{H}$ NMR (500 MHz, chloroform-d) $\delta \mathrm{ppm} 3.87$ (s, $\left.4 \mathrm{H}\right) 7.14(\mathrm{dd}, J=8.23,2.20 \mathrm{~Hz}, 2 \mathrm{H})$ 7.19-7.28 (m, $4 \mathrm{H}) 7.66$ (s, $2 \mathrm{H}) .{ }^{13} \mathrm{C}$ NMR $(126 \mathrm{MHz}$, chloroform- $d) \delta$ ppm 29.88, 76.76, 77.01, 77.27, $117.65,117.78,118.67,118.81,126.57,126.60,126.62,126.65,131.88,131.91,131.92,134.25,134.26,134.82$, $149.18,149.27,149.49,149.58,151.16,151.26,151.50,151.60,188.21$.

\subsection{Biological Evaluations}

\subsubsection{Cell Culture}

A panel of KRAS (T84, SW620 and LoVo) and BRAF (HT29, NCI-H508, RKO and LS411N) mutated human CRC cell lines were grown in Dulbecco's modified Eagle's medium (DMEM) containing $10 \%$ fetal bovine serum (FBS) and $1 \%$ penicillin/streptomycin at $37^{\circ} \mathrm{C}$ under $5 \% \mathrm{CO}_{2}$ while NHDF cells were cultured in DMEM with 5\% FBS under the same condition. The culture medium was replenished every two days until the cells reached $80-90 \%$ confluency for further usage. All cell lines (T84, ATCC ${ }^{\circledR}$ CCL-248 ${ }^{\mathrm{TM}}$; SW620, ATCC ${ }^{\circledR}$ CCL-227 ${ }^{\mathrm{TM}}$; LoVo, ATCC ${ }^{\circledR}$ CCL-229 ${ }^{\mathrm{TM}}$; HT-29, ATCC ${ }^{\circledR}$ HTB-38; NCI-H508, ATCC ${ }^{\circledR}$ CCL-253 ${ }^{\mathrm{TM}}$; RKO, ATCC ${ }^{\circledR}$ CRL-2577; LS411N, ATCC ${ }^{\circledR}$ CRL-2159; NHDF, ATCC ${ }^{\circledR}$ PCS-201-010 ${ }^{\mathrm{TM}}$ ) were purchased from American Type culture Collections (ATCC, Manassas, VA, USA).

\subsubsection{MTT Assay}

LoVo cells $\left(1.5-5 \times 10^{3}\right.$ cells/well) were seeded into a 96 well plate and incubated at $37^{\circ} \mathrm{C}$ and $5 \% \mathrm{CO}_{2}$ atmosphere for $24 \mathrm{~h}$. On the following day, the cell media were replaced with $100 \mu \mathrm{L}$ of test compounds at various concentration. The final concentration of DMSO in the well is $0.1 \%$. After $72 \mathrm{~h}$ of incubation, culture medium was removed and $100 \mu \mathrm{L}$ of MTT (thiazoyl blue tertrazolium bromide) solution $(0.5 \mathrm{mg} / \mathrm{mL}$ in culture media) was added. The resultant plates were then further incubated at $37^{\circ} \mathrm{C}$ for $4 \mathrm{~h}$. Upon completion, the MTT solution was removed and the formazan salts formed were dissolved in $100 \mu \mathrm{L}$ of DMSO. The absorbance was recorded with a microplate reader at $570 \mathrm{~nm}$. The $\mathrm{IC}_{50}$ values of tested compounds were calculated from three independent experiments. 


\subsubsection{Morphological Inspection}

LoVo cells $\left(5 \times 10^{4}\right.$ cells/well $)$ were seeded into a 12 well plate and incubated at $37^{\circ} \mathrm{C}$ and $5 \%$ $\mathrm{CO}_{2}$ atmosphere for $24 \mathrm{~h}$. Next, the culture media were replaced with $1 \mathrm{~mL}$ of test compounds at various concentration and further incubated for $24 \mathrm{~h}$. The final concentration of DMSO in the well is $0.1 \%$. The morphological changes of compound-treated cells were photographed using a fluorescent microscope.

\subsubsection{Colony Formation Assay}

LoVo cells $\left(1 \times 10^{3}\right.$ cells/well) were seeded into a 6-well plate and incubated at $37^{\circ} \mathrm{C}$ and $5 \% \mathrm{CO}_{2}$ atmosphere overnight. After incubation, the culture media were replaced with $3 \mathrm{~mL}$ of test compounds at various concentration and further incubated for seven days. Upon completion, cells were washed with PBS and fixed with $4 \%$ paraformaldehyde for $15 \mathrm{~min}$ followed by cell staining with $0.5 \%(w / v)$ crystal violet for $20 \mathrm{~min}$. The resultant plates were then washed with tap water and dried at room temperature. Upon drying, the plate image was photographed.

\subsubsection{Cell Cycle Analysis}

LoVo cells $\left(1 \times 10^{5}\right.$ cells/well) were seeded into a 6-well plate and incubated at $37^{\circ} \mathrm{C}$ and $5 \%$ $\mathrm{CO}_{2}$ atmosphere overnight. The seeded cells were then treated with different concentrations of tested compounds for $24 \mathrm{~h}$. Upon completion, cells were trypsinized and washed with PBS followed by fixation with $70 \%$ ethanol overnight at $4{ }^{\circ} \mathrm{C}$. Then, the fixed cells were centrifuged at $160 \times g$ for $5 \mathrm{~min}$ and the resultant cell pellet was washed twice with PBS. Subsequently, $20 \mu \mathrm{L}$ of DNAse-free RNAse A solution $(1 \mathrm{mg} / \mathrm{mL})$ was added to the cell-containing PBS and further incubated for $15 \mathrm{~min}$. Upon completion, $10 \mu \mathrm{L}$ of propidium iodide staining buffer $(10 \mathrm{mg} / \mathrm{mL})$ was added and the resulting mixture was further incubated for $20 \mathrm{~min}$ at $4{ }^{\circ} \mathrm{C}$ in the dark. Lastly, samples were analyzed with a flow-cytometer (ACEA Biosciences, Inc., San Diego, CA, USA) at the PE channel. The values presented are the means \pm SD of three independent experiments.

\subsubsection{Cell Apoptosis Analysis}

LoVo cells $\left(1 \times 10^{5}\right.$ cells/well) were seeded into a 6-well plate and incubated at $37{ }^{\circ} \mathrm{C}$ and $5 \%$ $\mathrm{CO}_{2}$ atmosphere overnight. The seeded cells were then treated with different concentrations of tested compounds for 24,48 and $72 \mathrm{~h}$. After treatments, cells were trypsinized and washed with PBS followed by the addition of $1 \times$ binding buffer $(500 \mu \mathrm{L})$, Annexin V-PE $(5 \mu \mathrm{L})$ and 7-AAD $(5 \mu \mathrm{L})$ solutions. The resulting mixture was then incubated in the dark at $4{ }^{\circ} \mathrm{C}$ for $20 \mathrm{~min}$. Upon completion, the mixture was analysed with a flow-cytometer at the PE and APC channel. The values presented are the means \pm SD of three independent experiments.

\subsubsection{Measurement of Intracellular Reactive Oxygen Species (ROS) Levels}

LoVo cells $\left(1 \times 10^{5}\right.$ cells/well $)$ were seeded into a 6-well plate and incubated at $37^{\circ} \mathrm{C}$ and $5 \% \mathrm{CO}_{2}$ atmosphere overnight. After incubation, the seeded cells were treated with $1 \mathrm{~mL}$ of $10 \mu \mathrm{M}$ DCFDA in culturing media for $1 \mathrm{~h}$. Upon completion, the cells were washed twice with PBS followed by treatments with $5 \mu \mathrm{M}$ of selected compounds for 24,48 and $72 \mathrm{~h}$. Then, the treated cells were harvested, washed and re-suspended in PBS followed by flow-cytometric analysis at the FITC channel.

\subsubsection{Western Blot Analyses}

Lovo cells $\left(1.5 \times 10^{4}\right.$ cells $\left./ \mathrm{cm}^{2}\right)$ were seeded in a T75 flask and incubated at $37{ }^{\circ} \mathrm{C}$ and $5 \% \mathrm{CO}_{2}$ atmosphere overnight. The seeded cells were then treated with selected compounds at $5 \mu \mathrm{M}$ of $2 \mathbf{e}$ for $24 \mathrm{~h}, 48 \mathrm{~h}$, and $72 \mathrm{~h}$. After treatment, the cells were harvested and lysed with phenylmethanesulfonyl fluoride (PMSF)-containing cell lysis buffer. The lysates were then centrifuged at $13,300 \times g$ for $15 \mathrm{~min}$ and the supernatant was collected. Protein concentrations of all samples were determined 
using a BCA assay kit (Thermo Scientific Inc., Waltham, MA, USA). Equal amounts of protein were electrophoresed in $12 \%$ and $20 \%$ SDS-polyacrylamide gel (SDS-PAGE), and electro-transferred onto a $0.22-\mu \mathrm{m}$ polyvinyldene difluoride membrane. Each membrane was blocked with $5 \%(w / v)$ skim milk at room temperature for $1 \mathrm{~h}$ followed by overnight incubation with specific primary antibodies (1:1000) at $4{ }^{\circ} \mathrm{C}$. Subsequently, the respective membrane was washed thrice with TBST $(0.05 \%(v / v)$ of tween-20) followed by $1 \mathrm{~h}$ incubation with secondary antibody (1:10,000). Upon completion, the membrane was washed thrice with $1 \mathrm{X}$ Tris-Buffered Saline, $0.1 \%$ Tween ${ }^{\circledR} 20$ Detergent (TBST) and the immune reactive bands were developed using SuperSignal West Dura Extended Duration Substrate (Thermo Scientific Inc., Waltham, MA, USA). Subsequently the blots were visualized with an Amersham Imager 600 system (GE Healthcare Bio-Sciences AB, Uppsala, Sweden). $\beta$-actin served as an internal control [47]. All primary antibodies (cPARP, \#5625; cCas-7, \#12827; B-actin, \#4967; cCas-9, \#9508; Cas-8, \#9746; Bad, \#9239; Bax, \#5023; Mcl-1, \#94296) except anti-Bcl-2 and anti-Bcl-xL were purchased from Cell signaling Technology (Beverly, MA, USA). Both anti-Bcl-2 (K200018M) and anti-Bcl-xL (K001595P) primary antibodies were purchased from Solarbio Life Sciences (Beijing, China).

\subsubsection{Molecular Docking}

Molecular docking studies were carried out using Discovery Studio 3.1 (Accelrys, San Diego, USA) on an Intel $^{\circledR}(\mathrm{TM}) 2$ Quad CPU Q8200 @2.33 GHz running under a Windows XP Professional environment.

(1) Receptor preparation

The crystal structure of Bcl-2 (PDB ID: 4LVT) was first obtained from the Protein Data Bank. Then, all water molecules and co-crystallized ligands were removed from the crystal structure to obtain the $\mathrm{Bcl}-2$ receptor. Prior to docking the selected compounds into $\mathrm{Bcl}-2$, the $\mathrm{Bcl}-2$ receptor underwent a protein preparation protocol with CHARMm force field.

(2) Ligand preparation

Co-crystallized ligand (ABT-263) and 2e were drawn with ChemDraw Ultra 12.0. Then, the structures were imported to the Discovery Studio 3.1 followed by the ligand preparation protocol with the default setting recommended by Accelrys. The prepared ligands were then subjected to ligand minimization with CHARMm force field before being used for docking analyses.

(3) Flexible docking

Minimized co-crystallized ligands were re-docked into their respective enzymes with several sets of amino acids as flexible residues. The top ranked conformations resulted from the docking experiment were compared to their original crystallographic confirmation in terms of RMSD. The parameters with lowest RMSD values were selected for the flexible docking of 2e. The flexible docking results were analyzed using Discovery Studio Visualizer v4.1.0.14169 (Accelrys, San Diego, CA, USA).

\section{Conclusions}

In summary, six diarylpentanoids were synthesized and investigated for their anti-cancer potential against a panel of KRAS- and BRAF-mutated CRC cell lines. Compound $2 \mathbf{e}$ was found to be the most potent candidate based on its low $\mathrm{IC}_{50}$ values and high chemotherapeutic index. The anti-proliferative study on LoVo cells shows that $2 \mathbf{e}$ could inhibit cell proliferation by triggering cell cycle arrest at the G2/M phase. Further cell apoptosis analysis revealed that $2 \mathbf{e}$ could induce intrinsic apoptosis by disrupting the cellular redox balance through its direct inhibitory effects on Bcl-2 protein. A subsequent molecular docking study suggested that the insertion of the thio group into the cycloalkane ring and the substitution of a hydrophobic moiety on the phenyl ring could improve the binding interactions between Bcl-2 and diarylpentanoids, thus leading to better anti-cancer activity. In conclusion, we believe that tetrahydro- $4 \mathrm{H}$-thiopyran-4-one-containing diarylpentanoids could be a new class of $\mathrm{Bcl}-2$ inhibitor that deserves further investigation in the search for new anti-cancer agents.

Supplementary Materials: The following are available online. Figure S1: NMR Spectral and HPLC Profile of Synthesized Compound 2a; Figure S2: NMR Spectral and HPLC Profile of Synthesized Compound 2b; Figure S3: 
NMR Spectral and HPLC Profile of Synthesized Compound 2c; Figure S4: NMR Spectral and HPLC Profile of Synthesized Compound 2e; FigureS5: NMR Spectral and HPLC Profile of Synthesized Compound 2f.

Author Contributions: Conceptualization, S.W.L., S.L.C., F.A. and K.Y.; methodology, S.W.L., S.L.C.; software, S.W.L.; validation, S.W.L., S.L.C., F.A. and K.Y.; data curation, S.W.L. and S.L.C. All authors wrote the manuscript. All authors have read and agreed to the published version of the manuscript

Funding: This research received no external funding.

Acknowledgments: The authors thank the Newton-Ungku Omar Fund (MR/P012795/1) and Universiti Putra Malaysia for supporting S.W.L. under the post-doctoral programme.

Conflicts of Interest: The authors declare no conflict of interest.

\section{References}

1. Bray, F.; Ren, J.-S.; Masuyer, E.; Ferlay, J. Global estimates of cancer prevalence for 27 sites in the adult population in 2008. Int. J. Cancer 2012, 132, 1133-1145. [CrossRef] [PubMed]

2. Fink, D.; Zheng, H.; Nebel, S.; Norris, P.S.; Aebi, S.; Lin, T.P.; Nehmé, A.; Christen, R.D.; Haas, M.; MacLeod, C.L.; et al. In vitro and in vivo resistance to cisplatin in cells that have lost DNA mismatch repair. Cancer Res. 1997, 57, 1841-1845. [PubMed]

3. Salonga, D.; Danenberg, K.D.; Johnson, M.; Metzger, R.; Groshen, S.; Tsao-Wei, D.D.; Lenz, H.J.; Leichman, C.G.; Leichman, L.; Diasio, R.; et al. Colorectal tumors responding to 5-fluorouracil have low gene expression levels of dihydropyrimidine dehydrogenase, thymidylate synthase, and thymidine phosphorylase. Clin. Cancer Res. 2000, 6, 1322-1327. [PubMed]

4. Rosales, J.; Leong, L.A. Chemotherapy for Metastatic Colorectal Cancer. J. Natl. Compr. Cancer Netw. 2005, 3, 525-529. [CrossRef] [PubMed]

5. Sundar, S.; Symonds, R.; Decatris, M.; Kumar, D.; Osman, A.; Vasanthan, S.; O’Byrne, K. Phase II trial of Oxaliplatin and 5-Fluorouracil/Leucovorin combination in epithelial ovarian carcinoma relapsing within 2 years of platinum-based therapy. Gynecol. Oncol. 2004, 94, 502-508. [CrossRef]

6. Soultati, A.; Mountzios, G.; Avgerinou, C.; Papaxoinis, G.; Pectasides, D.; Dimopoulos, M.-A.; Papadimitriou, C.A. Endothelial vascular toxicity from chemotherapeutic agents: Preclinical evidence and clinical implications. Cancer Treat. Rev. 2012, 38, 473-483. [CrossRef]

7. Hatcher, H.; Planalp, R.P.; Cho, J.; Torti, F.M.; Torti, S.V. Curcumin: From ancient medicine to current clinical trials. Cell. Mol. Life Sci. 2008, 65, 1631-1652. [CrossRef]

8. Koeberle, A.; Northoff, H.; Werz, O. Curcumin blocks prostaglandin E2 biosynthesis through direct inhibition of the microsomal prostaglandin E2 synthase-1. Mol. Cancer Ther. 2009, 8, 2348-2355. [CrossRef]

9. Cho, J.-W.; Lee, K.-S.; Kim, C.-W. Curcumin attenuates the expression of IL-1 $\beta$, IL-6, and TNF- $\alpha$ as well as cyclin E in TNF- $\alpha$-treated HaCaT cells; NF- $\mathrm{KB}$ and MAPKs as potential upstream targets. Int. J. Mol. Med. 2007, 19, 469-474. [CrossRef]

10. Shakibaei, M.; John, T.; Schulze-Tanzil, G.; Lehmann, I.; Mobasheri, A. Suppression of NF-kB activation by curcumin leads to inhibition of expression of cyclo-oxygenase-2 and matrix metalloproteinase-9 in human articular chondrocytes: Implications for the treatment of osteoarthritis. Biochem. Pharmacol. 2007, 73, 1434-1445. [CrossRef]

11. Chan, M.M.-Y.; Huang, H.-I.; Fenton, M.R.; Fong, D. In Vivo Inhibition of Nitric Oxide Synthase Gene Expression by Curcumin, a Cancer Preventive Natural Product with Anti-Inflammatory Properties. Biochem. Pharmacol. 1998, 55, 1955-1962. [CrossRef]

12. Kunnumakkara, A.B.; Anand, P.; Aggarwal, B.B. Curcumin inhibits proliferation, invasion, angiogenesis and metastasis of different cancers through interaction with multiple cell signaling proteins. Cancer Lett. 2008, 269, 199-225. [CrossRef]

13. Link, A.; Balaguer, F.; Shen, Y.; Lozano, J.-J.; Leung, H.-C.E.; Boland, C.R.; Goel, A. Curcumin Modulates DNA Methylation in Colorectal Cancer Cells. PLoS ONE 2013, 8, e57709. [CrossRef] [PubMed]

14. Liu, D.; Chen, Z. The Effect of Curcumin on Breast Cancer Cells. J. Breast Cancer 2013, 16, 133-137. [CrossRef] [PubMed]

15. Yallapu, M.M.; Maher, D.M.; Sundram, V.; Bell, M.C.; Jaggi, M.; Chauhan, S.C. Curcumin induces chemo/radio-sensitization in ovarian cancer cells and curcumin nanoparticles inhibit ovarian cancer cell growth. J. Ovarian Res. 2010, 3, 11. [CrossRef] 
16. Venkata, M.; Sripathy, R.; Anjana, D.; Somashekara, N.; Krishnaraju, A.; Krishanu, S.; Murali, M.; Verma, S.R.; Ramchand, C.N. In Silico, In Vitro and In Vivo Assessment of Safety and Anti-inflammatory Activity of Curcumin. Am. J. Infect. Dis. 2012, 8, 26-33. [CrossRef]

17. Aggarwal, B.B.; Shishodia, S.; Takada, Y.; Banerjee, S.; Newman, R.A.; Bueso-Ramos, C.E.; Price, J.E. Curcumin Suppresses the Paclitaxel-Induced Nuclear Factor-B Pathway in Breast Cancer Cells and Inhibits Lung Metastasis of Human Breast Cancer in Nude Mice. Clin. Cancer Res. 2005, 11, 7490-7498. [CrossRef]

18. Zhao, C.; Liu, Z.; Liang, G. Promising Curcumin-based Drug Design: Mono-carbonyl Analogues of Curcumin (MACs). Curr. Pharm. Des. 2013, 19, 2114-2135. [CrossRef]

19. Grogan, G. Emergent mechanistic diversity of enzyme-catalysed $\beta$-diketone cleavage. Biochem. J. 2005, 388, 721-730. [CrossRef]

20. Anand, P.; Kunnumakkara, A.B.; Newman, R.A.; Aggarwal, B.B. Bioavailability of Curcumin: Problems and Promises. Mol. Pharm. 2007, 4, 807-818. [CrossRef]

21. Liang, G.; Shao, L.; Wang, Y.; Zhao, C.-G.; Chu, Y.; Xiao, J.; Zhao, Y.; Li, X.; Yang, S. Exploration and synthesis of curcumin analogues with improved structural stability both in vitro and in vivo as cytotoxic agents. Bioorganic Med. Chem. 2009, 17, 2623-2631. [CrossRef]

22. Leong, S.W.; Faudzi, S.M.M.; Abas, F.; Aluwi, M.F.F.M.; Rullah, K.; Lam, K.W.; Bahari, M.N.A.; Ahmad, S.; Tham, C.L.; Shaari, K.; et al. Nitric oxide inhibitory activity and antioxidant evaluations of 2-benzoyl-6-benzylidenecyclohexanone analogs, a novel series of curcuminoid and diarylpentanoid derivatives. Bioorganic Med. Chem. Lett. 2015, 25, 3330-3337. [CrossRef] [PubMed]

23. Yang, B.; Zhang, M.; Gao, J.; Li, J.; Fan, L.; Xiang, G.; Wang, X.; Wang, X.; Wu, X.; Sun, Y.; et al. Small molecule RL71 targets SERCA2 at a novel site in the treatment of human colorectal cancer. Oncotarget 2015, 6, 37613-37625. [CrossRef] [PubMed]

24. Nakhjiri, M.; Safavi, M.; Alipour, E.; Emami, S.; Atash, A.F.; Jafari-Zavareh, M.; Ardestani, S.K.; Khoshneviszadeh, M.; Foroumadi, A.; Shafiee, A. Asymmetrical 2,6-bis(benzylidene)cyclohexanones: Synthesis, cytotoxic activity and QSAR study. Eur. J. Med. Chem. 2012, 50, 113-123. [CrossRef] [PubMed]

25. Manohar, S.; Khan, S.I.; Kandi, S.K.; Raj, K.; Sun, G.; Yang, X.; Molina, A.D.C.; Ni, N.; Wang, B.-H.; Rawat, D.S. Synthesis, antimalarial activity and cytotoxic potential of new monocarbonyl analogues of curcumin. Bioorganic Med. Chem. Lett. 2013, 23, 112-116. [CrossRef]

26. Subramaniam, D.; Nicholes, N.D.; Dhar, A.; Umar, S.; Awasthi, V.; Welch, D.R.; Jensen, R.A.; Anant, S. 3,5-bis(2,4-difluorobenzylidene)-4-piperidone, a novel compound that affects pancreatic cancer growth and angiogenesis. Mol. Cancer Ther. 2011, 10, 2146-2156. [CrossRef]

27. Kumar, B.; Yadav, A.; Hideg, K.; Kuppusamy, P.; Teknos, T.N.; Kumar, P. A Novel Curcumin Analog (H-4073) Enhances the Therapeutic Efficacy of Cisplatin Treatment in Head and Neck Cancer. PLoS ONE 2014, 9, e93208. [CrossRef]

28. Tan, X.; Sidell, N.; Mancini, A.; Huang, R.-P.; Wang, S.; Horowitz, I.R.; Liotta, D.C.; Taylor, R.N.; Wieser, F. Multiple Anticancer Activities of EF24, a Novel Curcumin Analog, on Human Ovarian Carcinoma Cells. Reprod. Sci. 2010, 17, 931-940. [CrossRef]

29. Pignanelli, C.; Ma, D.; Noel, M.; Ropat, J.; Mansour, F.; Curran, C.; Pupulin, S.; Larocque, K.; Wu, J.; Liang, G.; et al. Selective Targeting of Cancer Cells by Oxidative Vulnerabilities with Novel Curcumin Analogs. Sci. Rep. 2017, 7, 1105. [CrossRef]

30. Sun, J.; Wang, S.; Li, H.; Jiang, W.; Hou, G.-G.; Zhao, F.; Cong, W. Synthesis, antitumor activity evaluation of some new $\mathrm{N}$-aroyl- $\alpha, \beta$-unsaturated piperidones with fluorescence. J. Enzym. Inhib. Med. Chem. 2015, 31, 1-8. [CrossRef]

31. Pan, Y.; Wang, Y.; Cai, L.; Cai, Y.; Hu, J.; Yu, C.; Li, J.; Feng, Z.; Yang, S.; Li, X.; et al. Inhibition of high glucose-induced inflammatory response and macrophage infiltration by a novel curcumin derivative prevents renal injury in diabetic rats. Br. J. Pharmacol. 2012, 166, 1169-1182. [CrossRef]

32. Katsori, A.-M.; Chatzopoulou, M.; Dimas, K.; Kontogiorgis, C.; Patsilinakos, A.; Trangas, T.; Hadjipavlou-Litina, D. Curcumin analogues as possible anti-proliferative \& anti-inflammatory agents. Eur. J. Med. Chem. 2011, 46, 2722-2735. [CrossRef]

33. Tan, K.-L.; Koh, S.-B.; Ee, P.-L.R.; Khan, M.; Go, M.-L. Curcumin Analogues with Potent and Selective Anti-proliferative Activity on Acute Promyelocytic Leukemia: Involvement of Accumulated Misfolded Nuclear Receptor Co-repressor (N-CoR) Protein as a Basis for Selective Activity. ChemMedChem 2012, 7, 1567-1579. [CrossRef] 
34. Tan, K.-L.; Ali, A.; Du, Y.; Fu, H.; Jin, H.-X.; Chin, T.-M.; Khan, M.; Go, M.-L. Synthesis and Evaluation of Bisbenzylidenedioxotetrahydrothiopranones as Activators of Endoplasmic Reticulum (ER) Stress Signaling Pathways and Apoptotic Cell Death in Acute Promyelocytic Leukemic Cells. J. Med. Chem. 2014, 57, 5904-5918. [CrossRef]

35. Zamrus, S.N.H.; Akhtar, M.N.; Yeap, S.K.; Quah, C.K.; Loh, W.-S.; Alitheen, N.B.; Zareen, S.; Tajuddin, S.N.; Hussin, Y.; Shah, S.A.A. Design, synthesis and cytotoxic effects of curcuminoids on HeLa, K562, MCF-7 and MDA-MB-231 cancer cell lines. Chem. Central J. 2018, 12, 31. [CrossRef]

36. Schmitt, F.; Gold, M.; Begemann, G.; Andronache, I.; Biersack, B.; Schobert, R. Fluoro and pentafluorothio analogs of the antitumoral curcuminoid EF24 with superior antiangiogenic and vascular-disruptive effects. Bioorganic Med. Chem. 2017, 25, 4894-4903. [CrossRef]

37. Liang, G.; Li, X.; Chen, L.; Yang, S.; Wu, X.; Studer, E.; Gurley, E.; Hylemon, P.B.; Ye, F.; Li, Y.; et al. Synthesis and anti-inflammatory activities of mono-carbonyl analogues of curcumin. Bioorganic Med. Chem. Lett. 2008, 18, 1525-1529. [CrossRef]

38. Gindy, M.; Dwidar, I.M. 183. 3:4-Benzoxanthens. Part III. The synthesis and oxidation of 5-, 6-, 7-, and 8-methyl-3:4-benzoxanthen. J. Chem. Soc. 1953, 893-895. [CrossRef]

39. Leong, S.W.; Chia, S.L.; Abas, F.; Yusoff, K. Synthesis and in-vitro anti-cancer evaluations of multi-methoxylated asymmetrical diarylpentanoids as intrinsic apoptosis inducer against colorectal cancer. Bioorganic Med. Chem. Lett. 2020, 30, 127065. [CrossRef]

40. Leong, S.W.; Chia, S.L.; Abas, F.; Yusoff, K. Asymmetrical meta-methoxylated diarylpentanoids: Rational design, synthesis and anti-cancer evaluation in-vitro. Eur. J. Med. Chem. 2018, 157, 716-728. [CrossRef]

41. Cohen, G.M. Caspases: The executioners of apoptosis. Biochem. J. 1997, 326, 1-16. [CrossRef] [PubMed]

42. Shamas-Din, A.; Kale, J.; Leber, B.; Andrews, D.W. Mechanisms of Action of Bcl-2 Family Proteins. Cold Spring Harb. Perspect. Biol. 2013, 5, a008714. [CrossRef] [PubMed]

43. Aharoni-Simon, M.; Shumiatcher, R.; Yeung, A.; Shih, A.Z.L.; Dolinsky, V.W.; Doucette, C.A.; Luciani, D.S. Bcl-2 Regulates Reactive Oxygen Species Signaling and a Redox-Sensitive Mitochondrial Proton Leak in Mouse Pancreatic $\beta$-Cells. Endocrinology 2016, 157, 2270-2281. [CrossRef] [PubMed]

44. Veis, D.J.; Sorenson, C.M.; Shutter, J.R.; Korsmeyer, S.J. Bcl-2-deficient mice demonstrate fulminant lymphoid apoptosis, polycystic kidneys, and hypopigmented hair. Cell 1993, 75, 229-240. [CrossRef]

45. Hochman, A.; Sternin, H.; Gorodin, S.; Korsmeyer, S.; Ziv, I.; Melamed, E.; Offen, D. Enhanced oxidative stress and altered antioxidants in brains of Bcl-2-deficient mice. J. Neurochem. 1998, 71, 741-748. [CrossRef] [PubMed]

46. Nissink, J.W.M.; Murray, C.; Hartshorn, M.; Verdonk, M.L.; Cole, J.C.; Taylor, R. A new test set for validating predictions of protein-ligand interaction. Proteins Struct. Funct. Bioinform. 2002, 49, 457-471. [CrossRef]

47. Zhang, B.; Liu, Z.-Y.; Li, Y.-Y.; Luo, Y.; Liu, M.-L.; Dong, H.-Y.; Wang, Y.-X.; Liu, Y.; Zhao, P.-T.; Jin, F.-G.; et al. Antiinflammatory effects of matrine in LPS-induced acute lung injury in mice. Eur. J. Pharm. Sci. 2011, 44, 573-579. [CrossRef]

Sample Availability: Samples of the compounds are available from the authors.

(C) 2020 by the authors. Licensee MDPI, Basel, Switzerland. This article is an open access article distributed under the terms and conditions of the Creative Commons Attribution (CC BY) license (http://creativecommons.org/licenses/by/4.0/). 